\title{
Fulfillment of Children's Health Rights in Ambon City During The Covid 19 Pandemic
}

\author{
Veriena Josepha B Rehatta ${ }^{1 *}$, Wilshen Leatemia ${ }^{2}$, Tomy Palijama ${ }^{3}$ \\ 1, 2,3 Fakultas Hukum Universitas Pattimura, Ambon, Indonesia \\ *E-mail:verienajbr@gmail.com
}

Dikirim: 08/12/2021

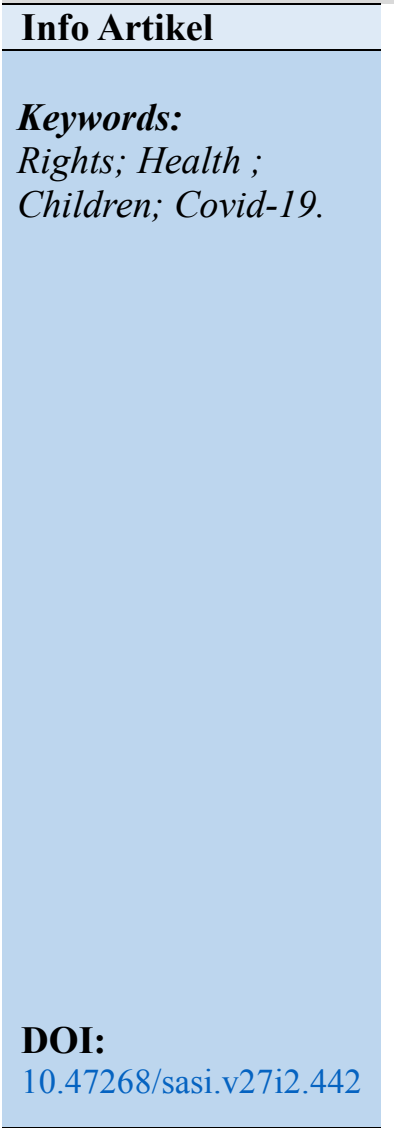

Direvisi: 28/04/2021

\begin{abstract}
Many challenges that can affect children's health, including access to health services, health disparities, social, cognitive, and emotional factors both in the family and society, environmental factors, especially poverty, and of course the Covid-19 virus are the main problems today. This study aims to see how the role of ambon city government in dealing with health problems in children during the Covid-19 pandemic and how the role and responsibility of the community in looking at health development in children during the Covid-19 pandemic. This research was conducted using a juridical approach emperis which is a descriptive study of qualitative analysis. The research seeks to illustrate how the Fulfillment of Children's Health Rights in Ambon City During the Covid-19 Pandemic. The workings of empirical juridical or sociological juridical methods in this research proposal are from the results of the collection and discovery of data and information through literature studies on the assumptions or basic assumptions used in answering the problems in this research, then conducted inductive-verifikative testing on the latest facts contained in society. The results of this study indicate that in the handling of the Covid19 Pandemic children in Ambon, it went well according to the Health protocol, as well as the services provided by the health officers at the puskesmas and the Ambon City Health Service to the exposed children, all were examined and treated properly. But there are also parents who do not bring their children to do an examination if they feel symptoms of Covid19. Therefore, the status of being exposed to Covid-19 in children is not so much because of the fear of parents to have their children checked.
\end{abstract}

\section{A. INTRODUCTION}

Corona virus is one in every of the main pathogens that primarily targets the human system. Previous outbreaks of corona viruse embody the severe acute metastasis syndrome (SARS)-CoV and also the area syndrome (MERS)-CoV that are antecedently characterised as agents that are an excellent public health threat. In late Gregorian calendar month 2019, a cluster of patients was admitted to hospitals with Associate in Nursing initial designation of respiratory illness of Associate in Nursing unknown etiology. These patients were epidemiologically 
connected to a food and animal wholesale market in the city of Wuhan, China ${ }^{1}$. Another report on Jan twenty four, 2020 calculable the accumulative incidence in China to be 5502 cases. $^{2}$

The beginning of the Covid-19 pandemic, children were referred to as an age group that was relatively unable to get infect with coronavirus. However, the Indonesian Association of Pediatrics (IDAI) points to the fact that the rate of transmission of coronavirus in children in Indonesia is quite high so it should make parents wary.Based on the official release of IDAI on May 18, 2020, no fewer than 584 children were declared positive for COVID-19 and 14 children died. Meanwhile, the number of children who died with the status of patients under supervision Covid-19 amounted to 129 people out of 3,324 children who were declared as patiens under supervision.

Corona virus or severe acute metabolic process syndrome coronavirus two (Sars-CoV-2) could be a virus that attacks the systema respiratorium. This illness because of virus infection is named Covid-19. The Corona virus will cause minor disturbances to the system respiratorium, severe respiratory organ infections, and death ${ }^{3}$. Severe acute metabolism syndrome coronavirus two (Sars-CoV-2), higher referred to as the Corona virus, could be a new variety of coronavirus that's transmitted to humans. The Corona infection is named Covid nineteen (Corona Virus unwellness 2019) and was initial discovered within the town of Wuhan, China at the top of December 2019. This virus is unfolding terribly quickly and has spread to the majority countries, together with Indonesia, in barely many months. Corona viruses are a collection of viruses that can infect the respiratory system. In many cases, they only cause mild respiratory infections, such as the flu.

Apart from the Sars-CoV-2 virus or the Corona virus, viruses that area unit are enclosed during this cluster are the viruses that cause Severe Acute metabolism Syndrome (Sars) and also the viruses that cause Severe Acute Respiratory Syndrome (Sars) and the viruses that cause Middle-East Respiratory Syndrome (Mers). Although caused by a deadly disease from identical cluster, specifically the coronavirus, Covid 519 has many variations with respiratory illness and Mers, together with in terms of the speed of unfold and therefore the severity of symptoms. The way the Covid-19 corona virus spreads is through droplets or vomiting (fomites), in close unprotected contact. Transmission of the corona virus or Covid-19 occurs between those who have been infected with people without disease pathogens. The spread of the Covid-19 corona virus through toilet seats, bathroom door handles, and sinks (fecal shedding) has occurred in some patients. However, the spread of the corona virus or Covid-19 with fecal shedding has not been a major transmission effort until now.

From data released by the Ministry of Women Empowerment and Child Protection, the high number of cases of coronavirus transmission in children in Indonesia until May 28, 2020, the total number of children exposed to COVID-19 reached 5 percent of the total cases reported to the government (Ministry of Women Empowerment and Child Protection, 2020). Currently, many challenges that can affect children's health, including access to health services, health disparities, social, cognitive, and emotional factors both in the family and society, environmental factors, especially poverty, and of course the Covid-19 virus are the main problems today. The American Centers for Disease Control and Prevention (CDC) states the symptoms of Covid-19 in children are not as fatal as adults. However, later, they revised the statement by mentioning that the symptoms of children infected with coronavirus are similar to

${ }^{1}$ Bogoch, I. I., Watts, A., Thomas-Bachli, A., Huber, C., Kraemer, M. U., \& Khan, K. (2020). Pneumonia of unknown aetiology in Wuhan, China: potential for international spread via commercial air travel. Journal of Travel Medicine, 27(2), taaa008

2 Wang, W., Tang, J., \& Wei, F. (2020). Updated Understanding ff The Outbreak of 2019 Novel Coronavirus (2019 $\square \mathrm{nCoV})$ in Wuhan, China. Journal of Medical Virology, 92(4), 441-447.

3 Corona Virus (COVID-19), Alodokter. https://www.alodokter.com/viruscorona\#: :text=Virus\%20Corona $\% 20$ atau $\% 20$ severe $\% 20$ acute,paru $\% 20$ yang $\% 20$ berat $\% 2 \mathrm{C} \% 20 \mathrm{hingga} \% 20 \mathrm{kema}$ tian. Accessed on July 5, 2020.

$$
\text { 188|S A S Vol. } 27 \text { No.2, April - Juni } 2021
$$


the condition Multisystem Inflamatory Syndrome in Children (MIS-C) ${ }^{4}$.

MIS-C could be a condition once a juvenile body elements are inflamed, like the center, lungs, kidneys, brain, skin, eyes, and biological process organs. Cdc explained that coronavirus is found in children and adults suffering from MIS-C. Signs of corona infection within the kid is fever, abdominal pain to symptom, vomiting, neck pain.appears rash and red eyes, feeling terribly tired. In severe cases, children affected by coronavirus can also show signs of emergency, such as shortness of breath, severe abdominal pain, and bluish lips and face. Children infected with coronavirus with mis-C symptoms above can lead to serious complications until death. However, most children can recover with medical treatment, especially if the symptoms are found early on.

Early childhood is an individual who is undergoing a fundamental developmental process for his or her future life. At an early stage, the child will experience considerable physical and mental development and growth. At this age, children will respond and process things that they receive quickly. Therefore, various things received by children at an early age will be the foundation for their future life. According to Rizqie Aulina (Aulina, 2011), balanced nutrition should be applied from an early age because this group belongs to an important age group and a critical group of human development that will determine the future quality of human life ${ }^{5}$.

Health is one of the main factors and is very important in the development of children. When the child's health condition is not healthy, it will have an impact on various things related to his development and to the various activities he will do. The main thing to maintain the health condition of the child is to pay attention to the nutrients contained in the food consumed. Good nutritional status is one of the determining factors of children's success in learning. Poor nutrition in the early first years of a child's age can result in a child's lack of focus, memory, and ability.

Food is a fundamental necessity for every human being on this earth. Food consumed by children plays a big role in their future life. Adequacy of nutrients that enter the child's body affects the health and intelligence of the child. The pattern of food consumed by children from an early age affects and even becomes the pattern of food that it carries until the end of the adult child. Therefore, the knowledge and ability of parents and adults around the child to manage healthy food is very important ${ }^{6}$. At this time, the rise of junk food and instant food is more favored by children. This makes it more difficult for children to be introduced to healthy foods full of nutrients and vitamins. The child grows and develops according to the nutritional intake he receives. Children always grow and develop from conception until finally adolescence. The child shows age-appropriate features of growth and development. In general, the growth and development of children has interconnected characteristics and the growth and development of children is the result of interaction of many factors that influence both things.

Families and children who fall poor in a short period of time will experience severe impacts in terms of household food safety and limitations related to access, availability, and affordability of healthy foodstuffs. An online survey showed that food needs were increasingly unsafe: 36 respondents said they "often" reduced portions of food due to financial problems. Loss of household income increases the risk of children experiencing micronutrients. Malnutrition is a dangerous form of malnutrition. The risk of death in children with the condition is almost 12 times higher than the risk of death in children with good nutrition. ${ }^{7}$

1.

${ }^{4}$ Marcdahte, K. J. (2014). Essential Child Health Sciences, Sixth Edition, Singapore: Hooi Ping Chee, h.

5 Inten, D. N., \& Permatasari, A. N. (2019). Literasi Kesehatan Pada Anak Usia Dini Melalui Kegiatan Eating Clean. Jurnal Obsesi: Jurnal Pendidikan Anak Usia Dini, 3(2), 366-376.

6 Ibid

7 Black, R. E., Allen, L. H., Bhutta, Z. A., Caulfield, L. E., De Onis, M., Ezzati, M., ... \& Maternal and Child Undernutrition Study Group. (2008). Maternal and child undernutrition: global and regional exposures and 189|SASI Vol. 27 No.2, April - Juni 2021 
Children who recover from malnutrition may continue to have developmental and growth problems throughout their life. Furthermore, efforts to reduce COVID-19 infection can make it difficult to identify and provide essential care and services for children who are malnourished. Indonesian was previously an example of a country with "three burdens of malnutrition", long before the Covid-19 pandemic Indonesia has 7 million children who are stunted. This condition makes Indonesia as the fifth country in the world with the most stunting toddlers. More than 2 million children are skinny toddlers (weight not proportional to height) and another 2 million children are overweight or obese ${ }^{8}$. Almost half of total pregnant women experience anemia because the food consumed does not contain enough vitamins and minerals (micronutrients) needed.

Indonesian faces complex challenges due to these three burdens that are likely to worsen due to the COVID-19 pandemic.Children can experience malnutrition for various reasons (direct causes, existing, and basic). The three most common direct causes of malnutrition are : (i) inadequate breastfeeding practices and poor diet, plus optimal parenting practices; (ii) inadequate nutrition and care for pregnant women and women; and (iii) high rates of infectious diseases primarily due to an unanime residential environment and inadequate access to inadequate health services. The spread of corona virus in Ambon is massive with the increasing number of patients in monitoring and people in surveillance who are vulnerable to coronavirus. The increasing number of positive infections of coronavirus in Ambon increases the chances of contracting the virus in toddlers and children with a low immune system makes children very vulnerable to corona virus.

\section{B. RESEARCH METHODS}

This research was conducted using an empirical juridical approach which is a descriptive study of qualitative analysis ${ }^{9}$. The location of this research is centered on the city of Ambon. The research tries to describe how the fulfillment of children's health rights in Ambon City during the Covid-19 pandemic. The workings of the juridical empirical or sociological juridical method in this research are from the results of collecting and finding data and information through literature study on the basic assumptions or assumptions used in answering the problems in this study, then inductive-verification testing is carried out on the latest facts that exist in society. This analysis is sourced from primary data and secondary data Primary data is data obtained directly from the general public, and secondary data on the regulation of primary materials, secondary legal materials and tertiary legal materials. Technique data in this research will be collected based on the problems formulated and classified according to the source to then be studied in a comprehensive and comprehensive manner.

\section{RESULTS AND DISCUSSION}

\section{Health Compliance Conditions At The Research Location}

The attention of the globe is justly centered on measures to mitigate the transmission and economic impact of the 2019 novel coronavirus unwellness (COVID-19) pandemic ${ }^{10}$. The Covid-19 pandemic that occurred in almost all of the world, shows the increasingly important role of the family in caring for, caring for and educating children.This incident restores the original function of the family as the center of all activities, places the occurrence of primary

\footnotetext{
health consequences. The lancet, 371(9608), 243-260. DOI: https://doi.org/10.1016/S0140-6736(07)61690-0

8 Ibid

9 Irwansyah. (2020). Penelitian Hukum: Pilihan Metode \& Praktik Penulisan Artikel. Yogyakarta: Mirra Buana Media, h. 152-153.

10 Dalton, L., Rapa, E., \& Stein, A. (2020). Protecting the psychological health of children through effective communication about COVID-19. The Lancet Child \& Adolescent Health, 4(5), 346-347.
}

$$
190 \text { |S ASI Vol. } 27 \text { No.2, April - Juni } 2021
$$


education for children ${ }^{11}$.

Efforts to improve the quality of human life in the health sector are a very broad and comprehensive effort, these efforts include increasing the fulfillment of public health, both physical and non-physical, for fulfilling the health of children in Ambon city in particular in facing the Covid-19 pandemic, indications area unit that with the increasing variety of patients and suspected cases, all provinces in Republic of Indonesia and, has caused public concern regarding COVID-19 outbreak infections, inflicting anxiety. ${ }^{12}$

The Covid-19 pandemic has alarming implications for individual and collective health and emotional and social functioning. In addition to providing treatment, already stretched health care suppliers have a crucial role in observance psychosocial wants and delivering psychosocial support to their patients, health care suppliers, and also the public - activities that ought to be integrated into general pandemic health care. ${ }^{13}$

From the above understanding, it can be understood that basically health problems involve all aspects of life and cover the entire time of human life, both past, present and present and future lives. Judging from the history of its development, there has been a change in the orientation of the value of thought regarding efforts to solve health problems. The process of changing the value orientation and thought is always developing in line with technological and socio-cultural developments. It is a matter of deliberation, negligence and excuses for forgiveness so that they are able to take responsibility; have intentional or negligent. Therefore, if a doctor commits deliberately or negligently which results in harm to the patient, he can be held responsible for the crime. ${ }^{14}$ For this reason, organizational and health management problems must always receive serious attention. Parents and health-care professionals square measure justly involved as a result of COVID-19 may be a novel sickness, with a weak evidence-base on that to formulate clinical selections ${ }^{15}$

In the context of such a complex and broad health sector development, it is highly felt that laws and regulations that support health efforts need to be further refined and improved. Judging from the juridical aspect, with the development of the national health system, the time has come to review and complement the laws and regulations in the health sector, by issuing a variety of more suitable legal products that can : (i) Provide good health protection, (ii) Health compliance according to WHO standards, (iii) Health fulfillment as part of a public policy that is evenly distributed to all levels of society during the Covid pandemic.

11 Kurniati, E., Alfaeni, D. K. N., \& Andriani, F. (2020). Analisis Peran Orang Tua dalam Mendampingi Anak di Masa Pandemi Covid-19. Jurnal Obsesi: Jurnal Pendidikan Anak Usia Dini, 5(1), 241-256.

12 Ardan, M., Rahman, F. F., \& Geroda, G. B. (2020). The influence of physical distance to student anxiety on COVID-19, Indonesia. Journal of Critical Reviews, 7(17), 1126-1132.

13 Pfefferbaum, B., \& North, C. S. (2020). Mental health and the Covid-19 pandemic. New England Journal of Medicine, 383(6), 510-512.

14 Sihotang, E. (2015). Tanggung Jawab Hukum Rumah Sakit dalam Pelayanan Kesehatan. Jakarta: Publisher P3DI Setjen DPR RI And Azza Grafika, p.1

15 Sinha, I. P., Harwood, R., Semple, M. G., Hawcutt, D. B., Thursfield, R., Narayan, O., ...\& Southern, K. W. (2020). COVID-19 infection in children. The Lancet Respiratory Medicine, 8(5), 446-447. 
Table 1.

Health Compliance Carried Out By Health Workers For Children

\begin{tabular}{lll}
\hline No & Handling Activities & \multicolumn{1}{c}{ Information } \\
\hline 1 & $\begin{array}{l}\text { Child Patients who are } \\
\text { confirmed at the time of } \\
\text { performing a positive } \\
\text { confirmed test and handling it } \\
\text { face to face. }\end{array}$ \\
\hline
\end{tabular}

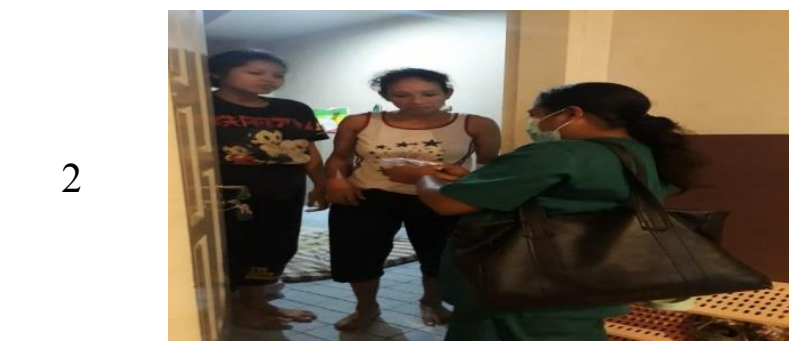

Examination and face-to-face with the family of the child patient who was confirmed positive when doing a quick test at the location of the salobar water health center.

\section{Legal Accountability In Fulfilling Children's Health In Ambon City}

The 1945 Constitution of state, Article 28H paragraph (1), say that : "everyone has the correct to measure in physical and mental prosperity, to live, and to possess an honest and healthy living surroundings and also the right to get health services". In paragraph (2), it's stated: "everyone has the correct to urge special facilities and treatment to urge a similar opportunities and edges so as to realize equality and justice". In paragraph (3), it's declared that "every person has the right to Social Security that allows his complete development as a dignified human being".In Article 34 paragraph (2) of the 1945 Constitution, it states : "the state develops a welfare system for all the individuals and empowers the weak and disadvantaged in line with to stay with human dignity ". In paragraph (3), it say: " the state is up to the mark of the the supply of correct health service facilities and public service facilities".

Law Number 36 of 2009 concerning Health, indicates that every individual, family and community has the right to receive protection for their health, and the state is responsible for regulating the fulfillment of the right to healthy life for its inhabitants, including for the poor and underprivileged. Efforts to realize this right, the government must provide health services that are equitable, fair and affordable for all levels of society. For this reason, the government needs to make efforts to ensure equal access for all residents to obtain health services. Indonesia as a developing country remains visaged with the matter of low public access to quality health services.

The delivery of health services is not able to answer the complexities of the delivery and financing of health services which are increasingly dependent on health technology which is increasingly expensive and complicated. The technology-intensive and increasingly expensive health service system demands professional handling by reliable institutions and demands an implementation method that is able to work effectively, efficiently and simultaneously satisfactorily. Regarding health services, the Fourth Amendment of the 1945 Constitution of the Republic of Indonesia, Article 34 paragraph (3) mandates that "the State is responsible for the provision of proper health service facilities and public service facilities". The phrase "appropriate" can be interpreted as saying that the state is not only responsible for providing adequate health facilities, but health facilities with certain standards that are deemed appropriate. As a legal term, health services can be found in Law No. 40 of 2004 on National Social Security 
(SJSN Law).

In Article 22 paragraph (1) it is emphasized: "Health insurance is a personal service in the form of health services that include promotive, preventive, curative and rehabilitative services, including drugs and necessary consumable medical materials". Law Number 40 of 2004 is an implementation of Article 28H and Article 34 of the 1945 NRI Constitution, so that the health services referred to in this law are in accordance with the meaning referred to in the $1945 \mathrm{NRI}$ Constitution.

The results of the second amendment to the 1945 Constitution of the Republic of Indonesia (UUD 1945) in 2000 included a more complete arrangement of human rights than before. Prior to the amendment, the content on human rights was contained in Article 27, Article 28, Article 29 paragraph (2), Article 30 paragraph (1), Article 31 paragraph (1), and Article 34. ${ }^{16}$ These provisions cover both civil and political fields (Sipol) as well as economic, social and cultural in a limited number and formulated briefly. ${ }^{17}$ Therefore, this regulation is deemed insufficient to accommodate all aspects of human rights which have developed so rapidly.

In the second amendment, the People's Consultative Assembly (MPR) included 10 new articles containing human rights contained in Article 28A, Article 28B, Article 28C, Article 28D, Article 28E, Article 28F, Article 28G, Article 28H, Article 28I, and Article 28J. The results of the addition of these articles are not only complete, but also detail human rights aspects. Thus, since the amendment, the articles of the 1945 Constitution governing human rights have become more complete and detailed. The existence of a more complete human rights regulation shows that the 1945 Constitution provides more guarantee and protection for human rights in Indonesia. This also proves the commitment of the Indonesian people to regulating and protecting human rights better than before. One of the types of human rights that have just been included in the 1945 Constitution is the right to health as stated in Article 28H paragraph (1) that reads " everyone has the rights to measure in physical and mental prosperity, to live, associate degreed to own associate degree honest and healthy living atmosphere so the proper to induce health services". Normatively, the 1945 Constitution doesn't state that the correct to health could be a right or a part of human rights.However, because Article $28 \mathrm{H}$ is contained in a chapter or articles regulating human rights, this material is considered human rights or part of human rights.

In addition, with regard to the right to health it is also regulated in Article 34 after the third amendment, especially in paragraph (3) and paragraph (4). In detail, Article 34 paragraph (3) reads "The state is responsible for the provision of proper health service facilities and public service facilities." Meanwhile, Article 34 paragraph (4) reads " "Further provisions relating to the implementation of this text are regulated in law." Based on the provisions of Article $28 \mathrm{H}$ and Article 34 of the 1945 Constitution, it is clear that the fulfillment of the right to health of every Indonesian citizen in the form of obtaining health facilities and public service facilities must be provided by the state. Fulfillment of human rights, including the right to health, is the responsibility of the state, especially the government, as emphasized in Article 28I paragraph (4) which reads "Protection, promotion, upholding and fulfillment of human rights for children is the responsibility of the state, especially the government." Therefore, the government is responsible for fulfilling the right to health as part of human rights. The implementation of government responsibilities is not only important but will also serve as a benchmark in improving people's lives as a manifestation of human rights.

In fact, the concept of human rights has two basic definitions that cannot be separated. First, the rights that cannot be separated and revoked are human rights because he is a human being. These rights are moral rights that derive from the humanity of every human being. The

16 Budiardjo, M. (2008). Dasar-Dasar Ilmu Politik, Jakarta: Gramedia Pustaka Utama, h. 248.

17 Ibid

193|SASI Vo1. 27 No.2, April - Juni 2021 
second definition of human rights is rights according to law, which are made in accordance with the law formation process of the community itself, both nationally and internationally. Thus, from the description above, it can be said that there are 3 (three) basic human rights, namely: First, basic human rights, namely personal rights, second, social rights, and third. Culture. The right to live a healthy life is actually an interaction and inter-relation of the three rights, personal rights and social rights and to some extent will become cultural rights as part of universal human rights. The right to a healthy life is specifically included in the Universal Declaration of Human Rights. In the article of the Human Rights Declaration which states that: "Everyone has the right to live at an adequate standard for their health and well-being, and that of their family, including the proper to have food, housing and health services" of living adequate for the health and well-being of himself and of his family, together with food, clothing, housing, and treatment".

With the above discourse it is clear that "health" is one of the main benchmarks of the development and national welfare of a nation. Thus "health" must become "mid-stream". Development is a "mid stream" of sustainable development, which is continuous. Not only as a marginal measure or a side live of the development of a nation and state as a result of health, healthy life is a right.

\section{CONCLUSION}

Health is a part of human rights and is one of the elements of welfare that must be realized in accordance with the aspirations of the Indonesian people as mandated by the Preamble to the 1945 Constitution of the Republic of Indonesia which contains constitutional guarantees of the right to health services as one of the human rights. Fulfillment of the right to health for children in the city of Ambon is still constrained by the presence of the child's parents who, in this case, object to letting their child be examined by medical personnel. This is because parents are afraid of the dangers of the Covid-19 pandemic and are also unwilling to see if their children have to be taken and quarantined in a different place. In handling the Covid-19 pandemic, the Ambon City Government has carried out good handling, but in dealing with this pandemic, facing a problem is that children are very vulnerable to Covid-19, but what is found in the field is that parents are still afraid to bring children to be Checking by the Covid-19 Task Force team in Ambon City is expected to provide testimony in 2021, so that it is hoped that the community and government can work together in tackling Covid-19. In accordance with the 1945 Constitution is the right to health as stipulated in Article $28 \mathrm{H}$ paragraph (1) which reads "Everyone has the right to live in physical and mental well-being, to have a place to live, and to have a good and healthy living environment and the right to obtain health services."

\section{REFERENCES}

\section{Journal}

[1] Ardan, M., Rahman, F. F., \& Geroda, G. B. (2020). The influence of physical distance to student anxiety on COVID-19, Indonesia. Journal of Critical Reviews, 7(17), 1126-1132.

[2] Black, R. E., Allen, L. H., Bhutta, Z. A., Caulfield, L. E., De Onis, M., Ezzati, M., ... \& Maternal and Child Undernutrition Study Group. (2008). Maternal and child undernutrition: global and regional exposures and health consequences. The lancet, 371(9608), 243-260. DOI: https://doi.org/10.1016/S0140-6736(07)61690-0.

[3] Bogoch, I. I., Watts, A., Thomas-Bachli, A., Huber, C., Kraemer, M. U., \& Khan, K. (2020). Pneumonia of unknown aetiology in Wuhan, China: potential for international spread via commercial air travel. Journal of Travel Medicine, 27(2), taaa008.

[4] Dalton, L., Rapa, E., \& Stein, A. (2020). Protecting the psychological health of children through effective communication about COVID-19. The Lancet Child \& Adolescent 
Health, 4(5), 346-347.

[5] Dinar Nur Arten, Andalusia Neneg Permatasari. (2019). Health Literacy In Early Childhood Through Eating Clean Activities. Obsession Journal: Journal of Early Childhood Education, 3(2), 366-376.

[6] Inten, D. N., \& Permatasari, A. N. (2019). Literasi Kesehatan Pada Anak Usia Dini Melalui Kegiatan Eating Clean. Jurnal Obsesi: Jurnal Pendidikan Anak Usia Dini, 3(2), 366-376.

[7] Kurniati, E., Alfaeni, D. K. N., \& Andriani, F. (2020). Analisis Peran Orang Tua dalam Mendampingi Anak di Masa Pandemi Covid-19. Jurnal Obsesi: Jurnal Pendidikan Anak Usia Dini, 5(1), 241-256.

[8] Pfefferbaum, B., \& North, C. S. (2020). Mental health and the Covid-19 pandemic. New England Journal of Medicine, 383(6), 510-512.

[9] Sinha, I. P., Harwood, R., Semple, M. G., Hawcutt, D. B., Thursfield, R., Narayan, O.,...\& Southern, K. W. (2020). COVID-19 infection in children. The Lancet Respiratory Medicine, 8(5), 446-447.

[10] Wang, W., Tang, J., \& Wei, F. (2020). Updated Understanding ff The Outbreak of 2019 Novel Coronavirus (2019 $\square \mathrm{nCoV}$ ) in Wuhan, China. Journal of Medical Virology, 92(4), 441-447.

\section{Book}

[11]Budiardjo, M. (2008). Dasar-Dasar Ilmu Politik, Jakarta: Gramedia Pustaka Utama.

[12] Irwansyah. (2020). Penelitian Hukum: Pilihan Metode \& Praktik Penulisan Artikel. Yogyakarta: Mirra Buana Media.

[13] Marcdahte, K. J. (2014). Essential Child Health Sciences, Sixth Edition, Singapore: Hooi Ping Chee.

[14] Sihotang, E. (2015). Tanggung Jawab Hukum Rumah Sakit dalam Pelayanan Kesehatan. Jakarta: Publisher P3DI Setjen DPR RI And Azza Grafika.

\section{Online/World Wide Web}

[15]Corona Virus (COVID-19), Alodokter. https://www.alodokter.com/viruscorona\#: :text=Virus\%20Corona\%20atau\%20severe\%20acute,paru\%20yang $\% 20$ berat $\%$ $2 \mathrm{C} \% 20$ hingga $\% 20$ kematian. 